\author{
Colombia Médica \\ colombiamedica.univalle.edu.co
}

\title{
Review
}

\section{A systematic review of observational studies on oxidative/nitrosative stress involvement in dengue pathogenesis}

\section{Revisión sistemática de los estudios observacionales sobre el papel del estrés oxidativo-nitrosativo en la patogénesis del dengue}

\author{
Raimundo Castro ${ }^{1,3}$, Hernando Samuel Pinzón², Nelson Alvis-Guzman²,3 \\ 1. University of San Buenaventura, Cartagena, Colombia. \\ 2. Children's Hospital Foundation Napoleon Franco Pareja, Cartagena, Colombia \\ 3. University of Cartagena, Cartagena, Colombia.
}

Castro R, Pinzón HS, Alvis-Guzman N. A systematic review of observational studies on oxidative/nitrosative stress involvement in dengue pathogenesis. Colomb Med. 2015; 46(3): 135-43.

(C) 2015. Universidad del Valle. This is an Open Access article distributed under the terms of the Creative Commons Attribution License, which permits unrestricted use, distribution, and reproduction in any medium, provided the original author and source are credited.

\section{Article history:}

Received: 15 January 2015

Revised: 09 June 2015

Accepted: 16 September 2015

Keywords:

Dengue; severe dengue; dengue virus; oxidative stress; nitrosative stress; biological markers; systematic review

Palabras clave:

Dengue; dengue grave; virus dengue; estrés oxidativo; marcadores biológicos; revisión sistemática.

\section{Abstract}

Objective: Our objective was to systematically review the published observational research related to the role of oxidative-nitrosative stress in pathogenesis of dengue.

Methods: We searched electronic databases (PubMed, EMBASE, The COCHRANE library, ScienceDirect, Scopus, SciELO, LILACS via Virtual Health Library, Google Scholar) using the term: dengue, dengue virus, severe dengue, oxidative stress, nitrosative stress, antioxidants, oxidants, free radicals, oxidized lipid products, lipid peroxides, nitric oxide, and nitric oxide synthase. Articles were selected for review by title and abstract excluding letter, review, in vivo and in vitro studies, and duplicates studies. Selected articles were reviewed for study design, original purposes, sample size, main outcomes, methods, and oxidative-nitrosative stress markers values. Results: In total, 4,331 non-duplicates articles were identified from electronic databases searches, of which 16 were eligible for full text searching. Data from the observational studies originate from Asian countries (50\%; 8/16), South American countries (31.2\%; 5/16), and Central America and the Caribbean countries (18.8\%; 3/16). Casecontrol study was the type of design most common in researches reviewed. The 1997 World Health Organization (WHO) dengue case classification criteria were used in all studies included in this review. Conclusions: Based on published data found in peer-reviewed literature, oxidative and nitrosative stress are demonstrated by changes in plasma levels of nitric oxide, antioxidants, lipid peroxidation and protein oxidation markers in patients with dengue infection. Additionally, elevated serum protein carbonyls and malondialdehyde levels appear to be associated with dengue disease severity.

\section{Resumen}

Objetivo: Sistematizar las evidencias observacionales sobre la relación entre el estrés oxidativo-nitrosativo y la patogénesis del dengue.

Métodos: Revisión sistemática de estudios observacionales en las bases de datos (PubMed, EMBASE, The COCHRANE library, ScienceDirect, Scopus, SciELO, LILACS via Virtual Health Library, Google Scholar) utilizando las siguientes palabras clave: dengue, dengue virus, severe dengue, oxidative stress, nitrosative stress, antioxidants, oxidants, free radicals, oxidized lipid products, lipid peroxides, nitric oxide y nitric oxide synthase. La selección inicial fue realizada a partir del título y resumen excluyéndose: cartas para editor, revisiones, estudios in vivo/in vitro y duplicados. A cada artículo seleccionado, se le revisó el diseño del estudio, objetivo, tamaño de la muestra, resultados principales y niveles plasmáticos de los marcadores de estrés oxidativo-nitrosativo.

Resultados: De 4,331 publicaciones encontradas, 16 estudios cumplieron con los criterios de inclusión. El $50 \%(8 / 16)$ de los estudios revisados fueron realizados en países de Sur América, Centro América y del Caribe. El diseño de casos y controles fue el más frecuente. El anterior sistema de clasificación de casos (OMS-1997) fue utilizado en todos los estudios incluidos en esta revisión. Conclusiones: El estrés oxidativo-nitrosativo se encuentra presente en el curso de la infección por virus dengue, demostrado por los cambios en las concentraciones plasmáticas de óxido nítrico, antioxidantes y marcadores de lipoperoxidación y de oxidación de proteínas. Por último, parece existir una asociación entre la elevación de los niveles plasmáticos de los carbonilos proteicos y malondialdehído con la severidad del dengue.

Corresponding author:

Raimundo Castro. Children's Hospital Foundation Napoleon Franco Pareja.

Phone: +57 314 5004087. E-mail: raimundo_castro_orozco@hotmail.com 


\section{Introduction}

Dengue is a systemic viralinfection with a significant socioeconomic and disease burden in many tropical and subtropical regions all over the world. Using cartographic approaches, one recent estimate indicates 390 million dengue infections per year (95\% credible interval 284-528 million), of which 96 million (95\% credible interval 67-136 million) manifest clinically (with any severity of disease) $)^{1}$.

The etiologic agent of this tropical disease is dengue virus (DENV), member of the family Flaviviridae, with four different antigenic serotypes (DENV-1 to -4). The DENV genome of plus strand RNA encodes three structural proteins (capsid, prM and envelope) and seven non-structural proteins (NS1, NS2a, NS2b, NS3, NS4a, NS4b y NS5) $)^{2,3}$

According to the PAHO, in 2013, for America reported 2,386,836 cases of dengue; of which 37,898 (1.6\%) corresponded to severe dengue, with case fatality rate 0.06 . Colombia, Andean country, reported 127,219 cases of dengue (55\% of cases reported in Andean Sub-region); of which 3,377 (81.1\% of cases reported in Andean Sub-region) corresponded to severe dengue ${ }^{4}$.

Clinical and epidemiological observations showed that dengue disease severity may vary according to age, ethnicity, genetic factors, immune status and underlying disease. It may also depend on the co-circulation of DENV serotypes and reinfection by different DENV serotypes ${ }^{5-9}$. In this respect, it has been proposed the involvement of DENV infection-derived oxidative stress on the severity of dengue. This is based on their ability to trigger the release of proinflammatory cytokines, including TNF-alpha, participating in collective action in the immunopathogenesis of dengue disease ${ }^{10}$.

By definition, oxidative stress is an imbalance between prooxidants and antioxidants in favour of the pro-oxidants ${ }^{11,12}$. Instead, nitrosative stress is defined as an indiscriminate nitrosilation of biological molecules ${ }^{13}$. In the absence of an appropriate compensatory response from endogenous antioxidant defense system, the activation of several stress-sensitive intracellular signaling pathways have been reported. This activation involves the production of gene products that can lead to cell death and/or pathophysiological conditions ${ }^{13-16}$.

The effects of DENV-derived oxidative stress and redox imbalance on human and animal cell cultures have been explored. The NO, ROS, and reactive nitrogen species-RNS levels, GSSG/GSH ratio, iNOS gene expression and phosphorylation of STAT-1 were increased during in vitro infection ${ }^{17-26}$.

Recently, Olagnier et al., ${ }^{27}$ have reported that nuclear factorerythroid 2-related factor $2 / \mathrm{Nrf}-2$ mediated oxidative stress response, iNOS signaling and production of NOS and ROS pathways were stimulated by DENV-2 infection of human monocyte-derived dendritic cells/Mo-DC. Also, a statistically significance decrease in SOD-2 mRNA levels was observed during treatment with ROS scavenger diphenyleneiodonium-DPI. In addition, these authors reported that DENV-2 infection was associated with NADPH oxidase-generated ROS accumulation.
These lines of evidence suggest that oxidative/nitrosative stress can be related to production of pathogenesis-related protein, increased susceptibility of mice to DENV infection, hemorrhage development in mice, proinflammatory cytokines and transcriptional factor expression, and DENV replication in various cell cultures.

Considering the aforementioned scenario, we performed a systematically review of observational studies evaluating the role of oxidative-nitrosative stress in pathogenesis of dengue. This review is important because understanding the involvement of oxidative and nitrosative stress in dengue pathogenesis could have potential implications for prognosis and treatment.

\section{Materials and Methods}

Search strategy

This review was guided by the standard PRISMA protocol (Preferred Reporting Items for Systematic Reviews and Metaanalysis) ${ }^{28}$ and was registered on PROSPERO, an international database of prospectively registered systematic reviews in health and social care managed by Center for Review and Dissemination, University of York, on 12 November 2014; http://www.crd.york. ac.uk/PROSPERO (CRD42014014878). PubMed, EMBASE, The COCHRANE library, ScienceDirect, Scopus, SciELO, LILACS via Virtual Health Library, Google Scholar databases were searched for articles using a combination of descriptors to select the studies of interest.

Study selection

After finding previously published studies in the databases with the descriptors "dengue" OR "dengue virus" combined with "oxidative stress" OR "nitrosative stress" OR "antioxidants" OR "oxidants" OR "free radicals" OR "oxidized lipid products" OR "lipid peroxides" OR "superoxide dismutase" OR "thioredoxin reductase" OR "nitric oxide" OR "nitric oxide synthase", we performed an analysis on the inclusion/exclusion criteria. This electronic search strategy was supplemented by scanning the reference lists of all articles to identify additional studies that may have been missed during the initial search.

As inclusion criteria, we used observational studies that evaluated oxidative-nitrosative stress in dengue pathogenesis. Exclusion criteria were impossible extraction of data, no control group, dates from mosquito cells cultures, the editorial, comments, case reports, letter to the editor, conference abstract, review articles, proteomics, in vitro and in vivo studies. When multiple publications from the same study population were available, we included the most recent publication.

Additionally, two authors reviewed the studies independently in case of disagreement a third author was consulted. In this systematic review, there is no restriction regarding to language, publication period, patient age (children or adult), or study design.

Data extraction strategy

Articles were selected for review by title and abstract. After reading full-text articles, we extracted data relating to study design, original purposes, sample size, main outcomes, methods, and oxidative stress markers values. 
The systematic computerized literature search of published observational studies was carried out in June 2014.

\section{Results}

Identification of studies

In total, 4,331 non-duplicates articles were identified from electronic databases searches, of which 16 were eligible for full text searching (Fig.1). Table 1 presents the citation, definitions and characteristics of each included studies, respectively.

Overview of included studies

Country of origin. Data from the observational research originate from India $(n=4)$, Thailand $(n=2)$, Singapore $(n=2)$, Cuba $(n=2)$, Guatemala $(n=1)$, Brazil $(n=2)$, Venezuela $(n=2)$, and, Colombia $(n=1)$.

Study design. Case-control study was the type of design most common in studies reviewed.

Age. The observational studies could be classified by the age range of participants: children (under $10 \mathrm{yrs}, \mathrm{n}=1$ ), adolescents (10 to 19 yrs, $n=1)$, children and adolescents $(n=1)$, adults (greater 19 yrs, $n=7)$, adolescents and adults $(n=3)$, children, adolescents and adults $(n=2)$, and age range: not reported $(n=1)$.

Follow-up time. Approximately 63\% of observational studies reported a 7-day follow-up period. About a quarter of the included studies did not report follow-up of participants.

Dengue case classification system. The 1997 World Health Organization (WHO) dengue case classification criteria were used in all studies included in this review.

As indicated in (Table 2), lipid peroxidation products (malondialdehyde-MDA, and hydroperoxides-THs), protein carbonyls (PCOs), antioxidant enzymes (superoxide dismutase$\mathrm{SOD}$, and glutathione peroxidase-GPx), nitric oxide, and reduced glutathione (GSH) levels were determined spectrophotometrically

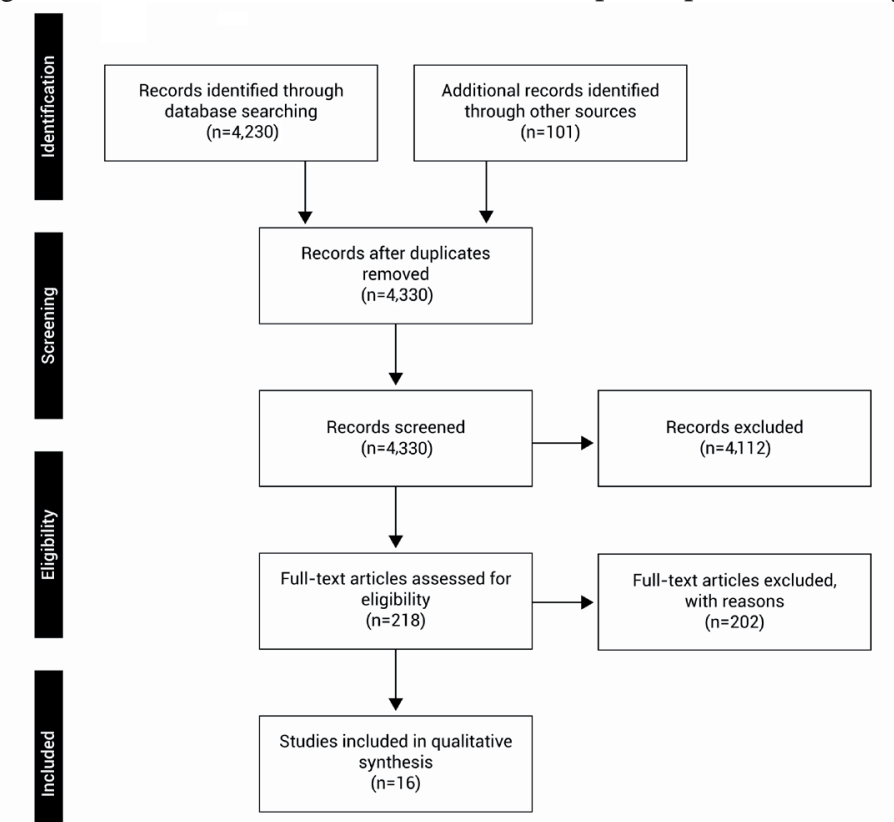

Figure 1. Flow diagram of studies included in the systematic review. or spectroflurometrically using commercial and non-commercial assays. The most analyzed oxidative-nitrosative stress markers were lipid peroxidation products $(35.7 \% ; 10 / 28)$, antioxidant enzymes $(17.9 \% ; 5 / 28)$, and nitric oxide $(10.7 \% ; 3 / 28)$.

\section{Discussion}

To our knowledge, no previous reviews on the involvement of oxidative-nitrosative stress in dengue pathogenesis have been performed. In the present systematic review, 16 articles concerning this subject were included.

The role of nitric oxide as strong immunomodulator and its association with viral infections, both in vivo and in vitro, have been clearly demonstrated ${ }^{29,30}$ but there are incongruous results in some studies in DENV-infected patients. For example, although elevated serum levels of nitric oxide have been observed in sera of patients with dengue fever (DF) in comparison to age-matched healthy controls ${ }^{25,31}$ or to patients with dengue hemorrhagic fever $(\mathrm{DHF})^{25}$, Trairatvorakul et al. ${ }^{32}$, reported that serum nitric oxide levels were significantly higher in healthy children than in DF or DHF patients. These studies were characterized by the low case/ control ratio $(\leq 1: 0.5)$.

Now, the two first reports are consistent with high total nitric oxide synthase activity and high L-arginine transport via system $\mathrm{y}^{+} \mathrm{L}$ reported in platelet obtained from DF and DHF patients compared with healthy adult controls ${ }^{33,34}$.

A study by Thai investigators reported that nitric oxide levels of primary and secondary DF, and primary DHF were not significantly different on the fever, defervescent or convalescent days in plasma of 37 DENV-infected children, while the level of serum nitric oxide was significantly lower on the fever day than on the defervescent day among children with secondary DHF. In addition, serum nitric oxide levels had an inverse correlation with the level of DENV viraemia in patients with secondary $\mathrm{DHF}^{22}$, but have not been linked to viral serotype infection ${ }^{31}$.

These observations are consistent with the findings of Yen et al. ${ }^{17}$, who reported a temporal coincidence between iNOS upregulation and free radical production with hemorrhage development in DENV-infected mice.

Blood nitrite and nitrate levels are frequently assessed as an index of systemic nitric oxide production. The spectrophotometric assay based on the Griess reagent is the most commonly used method to determine nitrite/nitrate concentration in biological matrixes ${ }^{35}$. In the (Table 2), the contrasting results may be explained by differences in nitrate reduction and deproteinization methods used or by differences in characteristics of populations studied.

As regard lipid peroxidation products as biomarkers for oxidative stress, several studies have found high serum levels of MDA and 4-hydroxyalkenals (4-HAE) in dengue patients in comparison to healthy adult controls ${ }^{10,36-38}$. Furthermore, others reported high serum MDA concentrations in DHF and dengue shock syndrome (DSS) patients than in DF patients. They also reported a positive correlation between serum MDA and TNF- $\alpha$ levels in all DENV-infected patients ${ }^{10}$. 
Table 1. Observational evidences of oxidative and nitrosative stress involvement in dengue pathogenesis

\begin{tabular}{|c|c|c|c|c|}
\hline $\begin{array}{l}\text { Study: author, Country, } \\
\text { Reference }\end{array}$ & Study Design & Original purposes & Sample size & Outcomes \\
\hline Ray, India, ${ }^{50}$ & Case-control & $\begin{array}{l}\text { To evaluate the status of antioxidants, enzymes } \\
\text { of hepatic and muscular origin and other } \\
\text { biochemical indicators in children with dengue } \\
\text { illness at admission }\end{array}$ & $\begin{array}{l}66 \text { children with dengue } \\
\text { ( } 45 \text { days to } 12 \text { yrs ) } \\
25 \text { healthy children } \\
\text { Follow-up period: none }\end{array}$ & $\begin{array}{l}\text { SOD: } \uparrow \text { Patients vs. Controls }(p<0.005) \\
\text { GPx: } \downarrow \text { Patients vs. Controls }(p<0.005)\end{array}$ \\
\hline Valero, Venezuela, ${ }^{34}$ & Case-control & $\begin{array}{l}\text { To determine the serum concentration of } \mathrm{NO} \text { in } \\
\text { patients with DF and DHF }\end{array}$ & $\begin{array}{l}105 \text { patients with dengue } \\
53 \text { healthy individuals } \\
\text { (Age-matched controls) } \\
\text { Follow-up period: none }\end{array}$ & $\begin{array}{l}\text { Nitric oxide: } \\
\uparrow \text { DF vs. DHF }(p<0.01) \\
\uparrow \text { DF vs. Controls }(p<0.01)\end{array}$ \\
\hline Gil, Cuba, ${ }^{39}$ & Case-control & $\begin{array}{l}\text { To study the status of some oxidative stress } \\
\text { markers in serologically confirmed adults } \\
\text { dengue patients comparing with those observed } \\
\text { in healthy individuals }\end{array}$ & $\begin{array}{l}22 \text { adults with dengue } \\
\text { ( } 21 \text { to } 58 \text { yrs) } \\
22 \text { healthy individuals } \\
\text { (Sex-and age-matched } \\
\text { controls) } \\
\text { Follow-up period: } 7 \text { days }\end{array}$ & $\begin{array}{l}\text { TAS (day 7): } \uparrow \text { Patients vs. Controls }(p \\
<0.05) \\
\text { PP - SOD - MDA/4-HAD (days 3-5-7): } \uparrow \\
\text { Patients vs. Controls }(p<0.05) \\
\text { THs - GPx (days 3-5-7): } \downarrow \text { Patients vs. } \\
\text { Controls }(p<0.05)\end{array}$ \\
\hline Klassen, Guatemala, ${ }^{40}$ & Case-control & $\begin{array}{l}\text { To report data of several micronutrients with } \\
\text { antioxidants in patients with classic dengue } \\
\text { fever during the acute phase and convalescence } \\
\text { from the disease and from appropriate reference } \\
\text { control subjects }\end{array}$ & $\begin{array}{l}9 \text { adults with dengue } \\
\text { (18 to } 68 \text { yrs) } \\
12 \text { healthy individuals } \\
\text { Follow-up period: } \\
\text { DI: admission to the } \\
\text { hospital } \\
\text { DII: } 5 \text { days after admission } \\
\text { (discharge) } \\
\text { DIII: } 7 \text { days after admis- } \\
\text { sion }\end{array}$ & $\begin{array}{l}\text { Retinol: } \downarrow \text { Patients (DI+DII)vs. Controls }(p<0.05) \\
\text { Retinol (patients): } \downarrow \text { DI vs. DIII }(p<0.05) \\
\text { b-carotene: } \downarrow \text { DII vs. DIII ( } p=0.03) \\
\text { GSH: } \downarrow \text { DII vs. DI ( } p=0.02 \text { ) } \\
\text { GSH (at DIII): } \downarrow \text { Patients vs. Controls }(p<0.05) \\
\text { TBARS (DI+DII): } \uparrow \text { Patients vs. Controls ( } p<0.05) \\
\text { TBARS (at DIII): } \uparrow \text { Patients vs. Controls ( } p<0.05) \\
\text { TAS (DI vs. DII): } \downarrow \text { Patients vs. Controls ( } p=0.01)\end{array}$ \\
\hline $\begin{array}{l}\text { Trairatvorakul, Thai- } \\
\text { land, }{ }^{35}\end{array}$ & Case-control & $\begin{array}{l}\text { To correlate nitric oxide levels in three groups } \\
\text { with different severity ranging from DF, DHF } \\
\text { I/II, to DSS, and to compare the results with a } \\
\text { control group }\end{array}$ & $\begin{array}{l}110 \text { children with dengue } \\
(<15 \text { yrs) } \\
38 \text { healthy children } \\
\text { (Age-matched controls) } \\
\text { Follow-up period: none }\end{array}$ & $\begin{array}{l}\text { Nitric oxide: } \\
\downarrow \text { Patients vs. Controls }(p<0.05) \\
\uparrow \text { DF vs. DHF I/II }(p<0.05) \\
\downarrow D H F \text { I/II vs. DSS }(p<0.05)\end{array}$ \\
\hline Rojas, Colombia, $^{51}$ & $\begin{array}{l}\text { Cross-sectional } \\
\text { study }\end{array}$ & $\begin{array}{l}\text { To evaluate the association between the levels of } \\
\text { glutathione peroxidase and the manifestations } \\
\text { and complications of dengue }\end{array}$ & $\begin{array}{l}161 \text { patients with dengue } \\
\text { (6 to } 85 \text { yrs) }\end{array}$ & $\begin{array}{l}\text { GPx: } \\
\uparrow \text { Patients with hemorrhages vs Patients } \\
\text { without hemorrhages }(p=0.03)\end{array}$ \\
\hline $\begin{array}{l}\text { Chareonsirisuthigul, } \\
\text { Thailand, }{ }^{25}\end{array}$ & $\begin{array}{l}\text { Cross-sectional } \\
\text { study }\end{array}$ & $\begin{array}{l}\text { To investigate the effect of antibody-dependent } \\
\text { enhancement infection on pro- and anti- } \\
\text { inflammatory cytokines production }\end{array}$ & $\begin{array}{l}60 \text { children with dengue } \\
\text { ( } 5 \text { to } 10 \mathrm{yrs} \text { ) }\end{array}$ & $\begin{array}{l}\text { Nitric oxide (secondary DHF): } \\
\downarrow \text { Fever day vs. Convalescent day }(p<0.05)\end{array}$ \\
\hline Soundravally, India, ${ }^{48}$ & Case-control & $\begin{array}{l}\text { To assess whether oxidative stress induced } \\
\text { changes in plasma protein can be an early } \\
\text { predictor of severe dengue disease }\end{array}$ & $\begin{array}{l}\text { (Sex- and age-matched } \\
\text { controls) } \\
\text { Follow-up period: none }\end{array}$ & $\begin{array}{l}\text { PCO: } \\
\uparrow \text { Patients vs. Controls }(p<0.001) \\
\downarrow \text { DF vs. DHF }(p<0.05) \\
\downarrow D F \text { vs. DSS }(p<0.05) \\
\downarrow D H F \text { vs. DSS }(p<0.05) \\
\text { PBSH: } \\
\downarrow \text { Patients vs. Controls }(p<0.001) \\
\uparrow \text { DF vs. DHF }(p<0.05) \\
\uparrow \text { DF vs. DSS }(p<0.05)\end{array}$ \\
\hline Soundravally, India, ${ }^{41}$ & Case-control & $\begin{array}{l}\text { To investigate the association of lipid } \\
\text { peroxidation and protein carbonylation with } \\
\text { thrombocytopenia in the different clinical } \\
\text { spectrum of dengue infection }\end{array}$ & $\begin{array}{l}80 \text { patients with dengue } \\
\text { (26-53 yrs) } \\
63 \text { healthy individuals } \\
\text { (Sex-and age-matched } \\
\text { controls) } \\
\text { Follow-up period: } \\
7 \text { days }\end{array}$ & $\begin{array}{l}\text { MDA ( } 3-5-7 \text { days): } \\
\uparrow \text { Patients vs. Controls }(p<0.05) \\
\downarrow \text { DF vs. DSS }(p<0.05) \\
\text { MDA (5-7 days): } \\
\downarrow \text { DF vs. DHF }(p<0.05) \\
\text { PCOs (7 day): } \\
\uparrow \text { Patients vs. Controls }(p<0.001) \\
\text { TAS ( } 3-5-7 \text { days): } \\
\downarrow D S S \text { vs. Controls }(p<0.05)\end{array}$ \\
\hline
\end{tabular}


Continued Table 1. Observational evidences of oxidative and nitrosative stress involvement in dengue pathogenesis

\begin{tabular}{|c|c|c|c|c|}
\hline $\begin{array}{l}\text { Study: author, Country, } \\
\text { Reference }\end{array}$ & Study Design & Original purposes & Sample size & Outcomes \\
\hline \multirow[t]{4}{*}{ Mendes-Ribeiro, Brazil, $^{36}$} & \multirow[t]{4}{*}{${ }^{6}$ Case-control } & \multirow[t]{4}{*}{$\begin{array}{l}\text { To investigate the effects of DF on the platelet } \\
\text { L-arginine-NO pathway, platelet function and an } \\
\text { inflammatory acute-phase protein fibrinogen }\end{array}$} & 16 patients with DF & 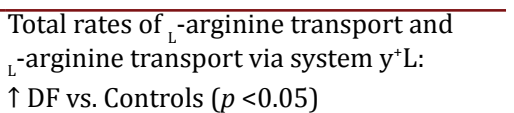 \\
\hline & & & 18 healthy controls & Total NOS activity: \\
\hline & & & (Age-matched controls) & $\uparrow \mathrm{DF}$ vs. Controls $(p<0.05)$ \\
\hline & & & Follow-up period: none & \\
\hline \multirow[t]{5}{*}{ Seet, Singapore, ${ }^{45}$} & \multirow[t]{5}{*}{ Case-control } & \multirow{5}{*}{$\begin{array}{l}\text { To investigate oxidative stress during dengue } \\
\text { infection }\end{array}$} & 28 patients with dengue & Plasma HETEs: \\
\hline & & & (23-68 yrs) & $\begin{array}{l}\uparrow \text { Febrile stage vs. Controls }(p<0.05) \\
\uparrow \text { Febrile stage vs. Convalescent stage }(p<0.05)\end{array}$ \\
\hline & & & 28 healthy controls & $\begin{array}{l}\text { COPs: } \\
\downarrow \text { Febrile stage vs. Controls }(p<0.05)\end{array}$ \\
\hline & & & (Age-matched controls) & Urinary $\mathrm{F}_{2}$-IsoPs: \\
\hline & & & Follow-up period: 25 days & $\uparrow$ Febrile stage vs. Convalescent stage $(p<0.05)$ \\
\hline \multirow[t]{12}{*}{ Lee, Singapore, ${ }^{46}$} & \multirow[t]{12}{*}{ Case-control } & \multirow{12}{*}{$\begin{array}{l}\text { To provide further insight into the relation } \\
\text { between lipid oxidation products and human } \\
\text { diseases }\end{array}$} & 35 patients with dengue & Plasma free $\mathrm{F}_{2}$-IsoPs: \\
\hline & & & (25-86 yrs) & $\uparrow$ DF onset vs. Controls $(p<0.01)$ \\
\hline & & & & $\uparrow D F$ onset vs. DF recovery $(p<0.01)$ \\
\hline & & & 47 healthy controls & Urinary $\mathrm{F}_{2}$-IsoPs: \\
\hline & & & & $\uparrow D F$ onset vs. Controls $(p<0.01)$ \\
\hline & & & & $\uparrow D F$ onset vs. DF recovery $(p<0.01)$ \\
\hline & & & (Age-matched controls) & Plasma total HETEs: \\
\hline & & & & $\uparrow$ DF onset vs. Controls $(p<0.01)$ \\
\hline & & & & $\uparrow D F$ onset vs. DF recovery $(p<0.01)$ \\
\hline & & & Follow-up period: none & COPs: \\
\hline & & & & $\downarrow D F$ onset vs. Controls $(p<0.05)$ \\
\hline & & & & $\downarrow D F$ onset vs. DF recovery $(p<0.05)$ \\
\hline \multirow[t]{5}{*}{ Levy, Venezuela, ${ }^{28}$} & \multirow{5}{*}{$\begin{array}{l}\text { Cross-sectional } \\
\text { study }\end{array}$} & \multirow{5}{*}{$\begin{array}{l}\text { To compare the serum levels of IL- } 6 \text {, TNFa, IL- } \\
1 \text { b, NO, CRP, C } 3 \text { and apoptosis in DENV-infected } \\
\text { patients and in monocytes/macrophages } \\
\text { cultures }\end{array}$} & 36 patients with DF & Nitric oxide: \\
\hline & & & $(3-53$ yrs) & $\begin{array}{l}\uparrow \text { DF vs. Controls }(p<0.001) \\
\uparrow D F \text { vs. DHF }(p<0.001)\end{array}$ \\
\hline & & & & $\uparrow$ Primary infection vs. Controls $(p<0.001)$ \\
\hline & & & 34 patients with DHF & $\uparrow$ Secondary infection vs. Controls $(p<0.001)$ \\
\hline & & & (3-53 yrs) & $\begin{array}{l}\downarrow \text { Primary infection vs. Secondary infection } \\
(p<0.001)\end{array}$ \\
\hline \multirow[t]{4}{*}{ Matsuura, Brazil, ${ }^{37}$} & \multirow[t]{4}{*}{ Case-control } & \multirow[t]{4}{*}{$\begin{array}{l}\text { To investigate }{ }_{L} \text {-arginine transport as well as } \\
\text { activity and expression of iNOS in DHF platelets }\end{array}$} & $\begin{array}{l}23 \text { patients with DHF } \\
(33 \pm 14 \text { yrs })\end{array}$ & $\mathrm{L}^{-\operatorname{arginine}}$ transport via system $\mathrm{y}^{+} \mathrm{L}$ : \\
\hline & & & 25 healthy individuals & $\uparrow$ DHF vs. Controls $(p<0.05)$ \\
\hline & & & (Age-matched controls) & Total NOS activity: \\
\hline & & & Follow-up period: none & $\downarrow$ DHF vs. Controls $(p<0.05)$ \\
\hline \multirow[t]{4}{*}{ Gil, Cuba, $^{44}$} & \multirow[t]{4}{*}{ Case-control } & \multirow{4}{*}{$\begin{array}{l}\text { To study the status of an extensive array of redox } \\
\text { indexes as proposal of an integral and dynamic } \\
\text { characterization of redox status }\end{array}$} & $\begin{array}{l}22 \text { patients with dengue } \\
\text { (18-84 yrs) }\end{array}$ & $\begin{array}{l}\text { MDA - HPO - SOD - PP: } \uparrow \text { Patients vs. } \\
\text { Controls }(p<0.05)\end{array}$ \\
\hline & & & 194 healthy individuals & GSH: \\
\hline & & & (Age-matched controls) & $\downarrow$ Patients vs. Controls $(p<0.05)$ \\
\hline & & & Follow-up period: 7 days & \\
\hline \multirow[t]{5}{*}{ Soundravally, India, ${ }^{13}$} & \multirow[t]{5}{*}{ Case-control } & \multirow{5}{*}{$\begin{array}{l}\text { To evaluate the levels of plasma MDA, TNF-a } \\
\text { and IFN-g during defervescence, in all the } \\
\text { three clinical groups of dengue compared to } \\
\text { uninfected blood samples }\end{array}$} & 81 patients with dengue & MDA: \\
\hline & & & (16-67 yrs) & $\downarrow$ DF vs. DHF $(p<0.001)$ \\
\hline & & & 30 healthy individuals & $\downarrow$ DF vs. DSS $(p<0.001)$ \\
\hline & & & $\begin{array}{l}\text { (Sex- and age-matched } \\
\text { controls) }\end{array}$ & $\downarrow$ DHF vs. DSS ( $p=0.017)$ \\
\hline & & & period: none & \\
\hline
\end{tabular}

DF: dengue fever; DHF: dengue hemorrhagic fever; SOD: superoxide dismutase; GSH: glutathione; GPX: glutathione peroxidase; ALB: albumin; CAT: catalase; MDA: malondialdehyde; PCO: protein carbonyl; HETEs: hydroxyl-eicosatetraenoic acid; COPs: cholesterol oxidative products; $\mathrm{F}_{2}$-ISOPs: $\mathrm{F}_{2}$-isoprostanes; TAS: total antioxidants status; HPO: hydroperoxides; PP: peroxidation potential; THs: total hydroperoxides. 
Interestingly, a recent study reported that DENV-2-infected mice showed alterations in oxidative stress by increasing the level of malondialdehyde $(\mathrm{MDA})^{18}$. These data together provide direct evidence for use end products of lipid peroxidation as prognostic biomarker in dengue disease.

Similar concentrations of MDA were reported using Satoh method $^{10,38}$. Both patients and healthy controls, Klassen et al., ${ }^{37}$ reported lower serum levels of MDA using Jentzch correction method. Instead, Gil et $a l^{36}$, reported high serum MDA concentrations in dengue patients. This sensible difference could be explained by detection of MDA in combination with 4-HAE and/or sensitivity and reproducibility of the method ${ }^{39}$.

Although THs levels are considered a measure of overall oxidative damage $^{40}$, there are no consistent pattern of THs in dengue disease. Gil et al. ${ }^{36}$, reported that serum THs concentrations were significantly decreased in dengue patients than in healthy adults. By contrast, the same group researchers recently reported elevated serum THs levels in dengue patients in comparison to adult controls ${ }^{41}$. In dengue cases, unlike controls, both studies reported similar serum THs concentrations.

Other oxidized lipid biomarkers have been studied. For example, isoprostanes (IsoPs), hydroxyeicosatetraenoic acid products (HETEs) and cholesterol oxidation products (COPs).

During febrile stage of dengue infection, high concentrations of urinary $\mathrm{F}_{2}$-IsoP and plasma HETEs levels have been detected in comparison with convalescent stage and also with healthy adults ${ }^{42}$. No significant differences were found in: (i) total $F_{2}$ IsoPs levels in all three dengue infection phases in comparison to adult controls ${ }^{42,43}$, (ii) urinary $\mathrm{F}_{2}$-IsoPs and plasma HETEs levels between defervescence and convalescence phases ${ }^{42}$, and (iii) total $\mathrm{F}_{2}$-IsoPs concentrations between onset of DF and recovery stage of DF. However, elevated plasma total HETEs levels and reduced COPs levels were observed in onset of DF than in recovery stage of DF or in controls ${ }^{43}$.

Table 2. Comparison of methods used and values reported in reviewed studies

\begin{tabular}{|c|c|c|c|}
\hline Markers & Methods & Reported values & References \\
\hline \multirow{13}{*}{ NO } & \multicolumn{3}{|l|}{ Spectrophotometric detection } \\
\hline & \multirow{5}{*}{ Absorbance at $540 \mathrm{~nm}$. (Griess reagent) } & DF cases (DENV-1): $57.4 \pm 3.02 \mathrm{mM}$ & \multirow{5}{*}{34} \\
\hline & & DF cases (DENV-4): $55.6 \pm 2.25 \mathrm{mM}$ & \\
\hline & & DHF cases (DENV-2): $13.87 \pm 2.05 \mathrm{mM}$ & \\
\hline & & DHF cases (DENV 4): $14.33 \pm 1.25 \mathrm{mM}$ & \\
\hline & & Controls: approx. $25 \mathrm{mM}$ & \\
\hline & \multirow{7}{*}{ Absorbance at $540 \mathrm{~nm}$. (Commercial kit, Griess method) } & DF cases: approx. $40 \mathrm{mM}$ & \multirow[t]{3}{*}{28} \\
\hline & & DHF cases: approx. $22 \mathrm{mM}$ & \\
\hline & & Controls: approx. $<10 \mathrm{mM}$ & \\
\hline & & DF cases: $124.94 \pm 36.79 \mathrm{mM}$ & \multirow[t]{4}{*}{35} \\
\hline & & DHF I/II cases: $99.69 \pm 33.42 \mathrm{mM}$ & \\
\hline & & DHF III/IV cases: $120.63 \pm 46.26 \mathrm{mM}$ & \\
\hline & & Controls: $168.18 \pm 24.10 \mathrm{mM}$ & \\
\hline \multirow{8}{*}{ MDA } & \multirow{2}{*}{ Absorbance at $532 \mathrm{~nm}$. (Satoh method) } & Dengue cases: $4.9 \pm 0.9 \mathrm{mM}$ & \multirow{2}{*}{13} \\
\hline & & Controls: $1.9 \pm 0.4 \mathrm{mM}$ & \\
\hline & \multirow{2}{*}{ Absorbance at $586 \mathrm{~nm} . \mathrm{MDA}+4$-HDA. (Commercial kit) } & Dengue cases: approx. 10-18 mM & \multirow{2}{*}{39} \\
\hline & & Controls: approx. $<10 \mathrm{mM}$ & \\
\hline & \multirow{2}{*}{ Difference in absorbances at 532 and $572 \mathrm{~nm}$. (Jentzsch method) } & Dengue cases: $0.624 \pm 0.144 \mathrm{mM}$ & \multirow{2}{*}{40} \\
\hline & & Controls: $0.450 \pm 0.116 \mathrm{mM}$ & \\
\hline & \multirow{2}{*}{ Absorbance at $532 \mathrm{~nm}$. (Satoh method) } & Dengue cases: approx. 2-8 mM & \multirow{2}{*}{41} \\
\hline & & Controls: approx. $2 \mathrm{mM}$ & \\
\hline \multirow{4}{*}{ THS } & \multirow{2}{*}{$\begin{array}{l}\text { Absorbance at } 560 \mathrm{~nm} \text {. Oxidation of Fe(II) to Fe (III) by THs. (Commercial } \\
\text { kit) }\end{array}$} & Dengue cases: approx. 50-150 mM & \multirow[t]{2}{*}{39} \\
\hline & & Controls: approx. $200-280 \mathrm{mM}$ & \\
\hline & \multirow{2}{*}{ Absorbance at $560 \mathrm{~nm}$. Oxidation of Fe(II) to Fe (III) by THs } & Dengue cases: $119.6 \pm 34.61 \mathrm{mM}$ & \multirow[t]{2}{*}{44} \\
\hline & & Controls: $70.3 \pm 13.9 \mathrm{mM}$ & \\
\hline \multirow{6}{*}{ PCOs } & \multirow{6}{*}{ Absorbance at $366 \mathrm{~nm}$. (Method of Levine) } & Dengue cases: approx. $3.0-8.0 \mathrm{nmol} / \mathrm{mg}$ protein & \multirow[t]{2}{*}{41} \\
\hline & & Controls: approx. $2.0-2.5 \mathrm{nmol} / \mathrm{mg}$ protein & \\
\hline & & DF cases: $4.98 \pm 0.47 \mathrm{nmol} / \mathrm{mg}$ protein & \multirow[t]{4}{*}{48} \\
\hline & & DHF cases: $5.95 \pm 0.61 \mathrm{nmol} / \mathrm{mg}$ protein & \\
\hline & & DSS cases: $6.66 \pm 0.70 \mathrm{nmol} / \mathrm{mg}$ protein & \\
\hline & & Controls: $1.97 \pm 0.56 \mathrm{nmol} / \mathrm{mg}$ protein & \\
\hline \multirow{8}{*}{ SOD } & \multirow[t]{4}{*}{ Absorbance at $505 \mathrm{~nm}$. (commercial kit) } & DENV cases: approx. 1.8-3.0 U/ml & 39 \\
\hline & & Controls: approx. 1.2-1.7 U/ml & \\
\hline & & DENV cases: $2.26 \pm 0.71 \mathrm{U} / \mathrm{mg} \mathrm{Hb}$ & 44 \\
\hline & & Controls: $1.41 \pm 0.72 \mathrm{U} / \mathrm{mg} \mathrm{Hb}$ & \\
\hline & Absorbance at $480 \mathrm{~nm}$. (Epinephrine method) & DF: $26.85 \pm 8.13 \mathrm{U} / \mathrm{ml}$ & 50 \\
\hline & & DHF: $23.17 \pm 9.98 \mathrm{U} / \mathrm{ml}$ & \\
\hline & & DSS: $24.86 \pm 9.22 \mathrm{U} / \mathrm{ml}$ & \\
\hline & & Controls: $2.31 \pm 0.97 \mathrm{U} / \mathrm{ml}$ & \\
\hline
\end{tabular}


With respect to PCOs content, it has been used as an important biomarker of protein oxidative damage in oxidative stress-related diseases in humans ${ }^{44}$. Elevated serum PCOs levels have been reported in dengue patients in comparison to adult controls. Moreover, elevated serum PCOs concentrations were associated with dengue disease severity ${ }^{38,45}$. In both studies reported similar serum PCOs levels using method of Levine.

By definition, oxidative stress also involves the antioxidant defensive system which is formed by ROS protective enzymes (SOD, GPx, glutathione reductase-GR, Catalase-CAT, thioredoxinTRX system, antioxidant nutrients, etc.), reactive oxygen species (ROS) scavengers (GSH, albumin, ascorbic acid, and uric acid), and sequestration of transition metal ions (transferrin, ferritin, metallothionein and ceruloplasmin $)^{46}$.

At all ages, elevated serum SOD levels and reduced GPx levels have been reported in dengue patients in comparison with controls ${ }^{36,41,47}$. By contrast, no differences were found in plasma antioxidants nutrients (except of retinol) concentrations between dengue patients and adult controls, but in this study only 9 patients and 12 healthy controls were evaluated ${ }^{37}$.

Results of one study have shown that serum GPx levels were associated with spontaneous bleeding events and with serum triglycerides levels in dengue patients. This finding suggests that the intensity of oxidative stress can influence the clinical presentation of dengue ${ }^{48}$. In this regard, a recent study reported that increased triglycerides levels were observed mainly in severe dengue patients ${ }^{49}$. Based on these data, it is likely that serum lipid profile in DENV-infected patients plays an important role in dengue severity.

Free radical production and alterations in antioxidants status occur during dengue disease ${ }^{37}$. The major antioxidant defense system appears to function by scavenging radical free radical. Nonenzymatic scavenger like GSH has been shown to be an effective protector against oxidative damage ${ }^{46}$. There are differences in the reports on the comparison of GSH concentrations in dengue patients and healthy controls. Gil et al. ${ }^{36}$, and Klassen et al. ${ }^{37}$, reported that serum GSH levels were not significantly different between patients and controls, whereas Gil et al. ${ }^{41}$, reported that serum GSH concentrations were significantly lower in dengue patients than in healthy adults controls. It is important to note two aspects: (i) these three researches were conducted in Central America and the Caribbean countries and (ii) the number of patients studied was small ( $\mathrm{n} \leq 22)$.

Despite the limitations of systematic reviews of observational studies, given the evidences presented here, oxidative-nitrosative stress is demonstrated by changes in plasma levels of nitric oxide, antioxidants, lipid peroxidation and protein oxidation markers in patients with dengue infection.

Additionally, elevated serum PCOs and MDA levels appear to be associated with dengue disease severity, expressed in terms of the 1997-WHO dengue case classification system. Accordingly, more data are needed to establish an association between oxidativenitrosative stress and dengue severity in the context of 2009-WHO dengue classification scheme.

\section{Conclusions}

Based on published data found in peer-reviewed literature, oxidative and nitrosative stress are demonstrated by changes in plasma levels of nitric oxide, antioxidants, lipid peroxidation and protein oxidation markers in patients with dengue infection. Additionally, elevated serum protein carbonyls and malondialdehyde levels appear to be associated with dengue disease severity.

There have been many studies that target the severity of dengue infections. However, our understanding is not complete yet. Better understanding of relation between oxidative-nitrosative stress and dengue pathogenesis will lead us to developing better prognostic strategies of this pathology.

Acknowledgements:

We thank Dr. Salim Mattar (University of Cordoba-Colombia) and Dr. Fernando de la Hoz (National Institute Health-Colombia) for their useful suggestions and comments.

Conflicts of interest:

The authors declare no conflict of interest.

\section{References}

1. Bhatt S, Gething PW, Brady OJ, Messina JP, Farlow AW, Moyes $\mathrm{CL}$, et al. The global distribution and burden of dengue. Nature. 2013;496(7446):504-507.

2. Sadon N, Delers A, Jarman RG, Klungthong C, Nisalak A, Gibbons RV, et al. A new quantitative RT-PCR method for sensitive detection of dengue virus in serum samples. J Virol Methods. 2008;153(1):1-6.

3. Mangold KA, Reynolds SL. A review of dengue fever: a resurging tropical disease. Pediatr Emerg Care. 2013;29(5):665-669.

4. PHAO . Number of Reported Cases of Dengue and Figures for 2013 (to week noted by each country) Epidemiological Week / EW 52. Washington, DC: PAHO; 2014. [28 Jul 2015]. a Available from: http:// reliefweb.int/report/honduras/number-reported-cases-dengue-andsevere-dengue-sd-americas-country-figures-2014-week.

5. Laughlin CA, Morens DM, Cassetti MC, Costero-Saint Denis A, San Martin JL, Whitehead SS, et al. Dengue research opportunities in the Americas. J Infect Dis. 2012;206(7):1121-1127.

6. Guzman A, Isturiz RE. Update on the global spread of dengue. Int J Antimicrob Agents. 2010;36(1):S40-S42.

7. World Health Organization . Dengue Guidelines for Diagnosis, Treatment, Prevention and Control. New Edition. Geneva: WHO Guidelines Approved by the Guidelines Review Committee; 2009. pp. 147-147.

8. Malavige GN, Fernando S, Fernando DJ, Seneviratne SL. Dengue viral infections. Postgrad Med J. 2004;80(948):588-601.

9. Guzman MG, Kouri G. Dengue diagnosis, advances and challenges. Int J Infect Dis. 2004;8(2):69-80. 
10. Soundravally R, Hoti SL, Patil SA, Cleetus CC, Zachariah $\mathrm{B}$, Kadhiravan $\mathrm{T}$, et al. Association between proinflammatory cytokines and lipid peroxidation in patients with severe dengue disease around defervescence. Int J Infect Dis. 2014;18:68-72.

11. Halliwell B. Biochemistry of oxidative stress. Biochem Soc Trans. 2007;35(5):1147-1150.

12. Giustarini D, Dalle-Donne I, Tsikas D, Rossi R. Oxidative stress and human diseases: Origin, link, measurement, mechanisms, and biomarkers. Crit Rev Clin Lab Sci. 2009;46(5-6):241-281.

13. Heinrich TA, da Silva RS, Miranda KM, Switzer CH, Wink DA, Fukuto JM. Biological nitric oxide signalling: chemistry and terminology. Br J Pharmacol. 2013;169(7):1417-1429.

14. Evans JL, Goldfine ID, Maddux BA, Grodsky GM. Oxidative stress and stress-activated signaling pathways: a unifying hypothesis of type 2 diabetes. Endocr Rev. 2002;23(5):599-622.

15. Dias AS, Porawski M, Alonso M, Marroni N, Collado PS, Gonzalez-Gallego J. Quercetin decreases oxidative stress, NF-kappaB activation, and iNOS overexpression in liver of streptozotocininduced diabetic rats. J Nutr. 2005;135(10):2299-2304.

16. Orr WC, Sohal RS. Effects of $\mathrm{Cu}-\mathrm{Zn}$ superoxide dismutase overexpression of life span and resistance to oxidative stress in transgenic Drosophila melanogaster. Arch Biochem Biophys. 1993;301(1):34-40.

17. Yen YT CH, Lin YD, Shieh CC, Wu-Hsieh BA. Enhancement by tumor necrosis factor alpha of dengue virus-induced endothelial cell production of reactive nitrogen and oxygen species is key to hemorrhage development. J Virol. 2008;82(24):12312-12324.

18. Wang J CY, Gao N, Wang Y, Tian Y, Wu J, Zhang J, Zhu J, Fan $\mathrm{D}$, An J. Inhibitory effect of glutathione on oxidative liver injury induced by dengue virus serotype 2 infections in mice. PloS One. 2013;8(1):55407-55407.

19. Marianneau P SA, Royer C, Drouet MT, Jaeck D, Kirn A, Deubel V. Infection of primary cultures of human Kupffer cells by Dengue virus: no viral progeny synthesis, but cytokine production is evident. J Virol. 1999;73(6):5201-5206.

20. Jan JT CB, Ma SH, Liu CI, Tsai HP, Wu HC, Jiang SY, Yang KD, Shaio MF. Potential dengue virus-triggered apoptotic pathway in human neuroblastoma cells: arachidonic acid, superoxide anion, and NF-kappaB are sequentially involved. J Virol. 2000;74(18):8680-8691.

21. Neves-Souza PC AE, Zagne SM, Valls-de-Souza R, Reis SR, Cerqueira DI, Nogueira RM, Kubelka CF. Inducible nitric oxide synthase (iNOS) expression in monocytes during acute Dengue Fever in patients and during in vitro infection. BMC Infect Dis. 2005;5:64-64.

22. Chareonsirisuthigul T, Kalayanarooj S, Ubol S. Dengue virus (DENV) antibody-dependent enhancement of infection upregulates the production of anti-inflammatory cytokines, but suppresses anti-DENV free radical and pro-inflammatory cytokine production, in THP-1 cells. J Gen Virol. 2007;88(2):365-375.

23. Tian Y JW, Gao N, Zhang J, Chen W, Fan D, Zhou D, An J. Inhibitory effects of glutathione on dengue virus production. Biochem Biophys Res Commun. 2010;397(3):420-424.

24. Lin YL LC, Chuang JI, Lei HY, Yeh TM, Lin YS, Huang YH, Liu HS. Involvement of oxidative stress, NF-IL-6, and RANTES expression in dengue-2-virus-infected human liver cells. Virology. 2000;276(1):114-126.

25. Levy A, Valero N, Espina LM, Anez G, Arias J, Mosquera J. Increment of interleukin 6, tumour necrosis factor alpha, nitric oxide, C-reactive protein and apoptosis in dengue. Trans R Soc Trop Med Hyg. 2010;104(1):16-23.

26. Al-Alimi AA AS, Al-Hassan FM, Idris FM, Teow SY, Mohd Yusoff N. Dengue virus type 2 (DENV2)-induced oxidative responses in monocytes from glucose-6-phosphate dehydrogenase (G6PD)-deficient and G6PD normal subjects. PLoS Negl Trop Dis. 2014;8(3):2711-2711.

27. Olagnier D PS, Steel C, van Montfoort N, Chiang C, Beljanski V, Slifker M, He Z, Nichols CN, Lin R, Balachandran S, Hiscott J. Cellular oxidative stress response controls the antiviral and apoptotic programs in dengue virus-infected dendritic cells. PLoS Pathog. 2014;10(12):1004566-1004566.

28. Moher D, Liberati A, Tetzlaff J, Altman DG, Group P. Preferred reporting items for systematic reviews and meta-analyses: the PRISMA Statement. Open Med. 2009;3(3):e123-e130.

29. Wink DA, Hines HB, Cheng RY, Switzer CH, Flores-Santana W, Vitek MP, et al. Nitric oxide and redox mechanisms in the immune response. J Leukoc Biol. 2011;89(6):873-891.

30. Chaturvedi UC, Nagar R. Nitric oxide in dengue and dengue haemorrhagic fever: necessity or nuisance? FEMS Immunol Med Microbiol. 2009;56(1):9-24.

31. Chareonsirisuthigul T, Kalayanarooj S, Ubol S. Dengue virus (DENV) antibody-dependent enhancement of infection upregulates the production of anti-inflammatory cytokines, but suppresses anti-DENV free radical and pro-inflammatory cytokine production, in THP-1 cells. J Gen Virol. 2007;88(2):365-375.

32. Trairatvorakul $\mathrm{P}$, Chongsrisawat $\mathrm{V}$, Ngamvasinont $\mathrm{D}$, Asawarachun D, Nantasook J, Poovorawan Y. Serum nitric oxide in children with dengue infection. Asian Pac J Allergy Immunol. 2005;23(2-3):115-119.

33. Mendes-Ribeiro AC MM, Siqueira MA, Moraes TL, Ellory JC, Mann GE, Brunini TM. Dengue fever activates the L-argininenitric oxide pathway: an explanation for reduced aggregation of human platelets. Clin Exp Pharmacol Physiol. 2008;35(10):11431146.

34. Matsuura C, Moraes TL, Barbosa JB, Moss MB, Siqueira MA, Mann GE, et al. Nitric oxide activity in platelets of 
dengue haemorrhagic fever patients: the apparent paradoxical role of ADMA and 1-NMMA. Trans R Soc Trop Med Hyg. 2012;106(3):174-179.

35. Sun J, Zhang X, Broderick M, Fein H. Measurement of nitric oxide production in biological systems by using Griess Reaction Assay. Sensors. 2003;3:276-284.

36. Gil L, Martinez G, Tapanes R, Castro O, Gonzalez D, Bernardo $\mathrm{L}$, et al. Oxidative stress in adult dengue patients. Am J Trop Med Hyg. 2004;71(5):652-657.

37. Klassen P, Biesalski HK, Mazariegos M, Solomons NW, Furst P. Classic dengue fever affects levels of circulating antioxidants. Nutrition. 2004;20(6):542-547.

38. Soundravally R, Sankar P, Bobby Z, Hoti SL. Oxidative stress in severe dengue viral infection: association of thrombocytopenia with lipid peroxidation. Platelets. 2008;19(6):447-454.

39. Srour MAB, Y Y.Y; Juma, M. Evaluation of different methods used to measure malonyldialdehyde in human erythrocytes. Clin Hemorheol Microcirc. 2000;23(1):23-30.

40. Kakita H, Hussein MH, Daoud GA, Kato T, Murai H, Sugiura $\mathrm{T}$, et al. Total hydroperoxide and biological antioxidant potentials in a neonatal sepsis model. Pediatr Res. 2006;60(6):675-679.

41. Gil dVL, Leon OS, Pérez J, Gonzalez I, Milian LC, Guevara M. Characterization of oxidative stress in different clinical conditions, using redox indexes of diagnostic value. Biotecnol Aplic. 2012;29:175-183.

42. Seet RC, Lee CY, Lim EC, Quek AM, Yeo LL, Huang SH, et al. Oxidative damage in dengue fever. Free Rad Biol Med. 2009;47(4):375-380.
43. Lee CY, Seet RC, Huang SH, Long LH, Halliwell B. Different patterns of oxidized lipid products in plasma and urine of dengue fever, stroke, and Parkinson's disease patients: cautions in the use of biomarkers of oxidative stress. Antioxid Redox Signal. 2009;11(3):407-420.

44. Dalle-Donne I, Rossi R, Giustarini D, Milzani A, Colombo R. Protein carbonyl groups as biomarkers of oxidative stress. Clin Chim Acta. 2003;329(1-2):23-38.

45. Soundravally R, Sankar P, Hoti SL, Selvaraj N, Bobby Z, Sridhar MG. Oxidative stress induced changes in plasma protein can be a predictor of imminent severe dengue infection. Acta Trop. 2008;106(3):156-161.

46. Noori S. An Overview of Oxidative Stress and Antioxidant Defensive System. Vitamins Trace Elements. 2012;1(8):413-413. 47. Ray G, Kumar V, Kapoor AK, Dutta AK, Batra S. Status of antioxidants and other biochemical abnormalities in children with dengue fever. J Trop Pediatr. 1999;45(1):4-7.

48. Rojas E, Díaz-Quijano FA, Coronel-Ruiz C, Martínez-Vega RA, Rueda E, Villar-Centeno LA. Correlación entre los niveles de glutatión peroxidasa y presentación clínica del dengue. Rev Med Chil. 2007;135(6):743-750.

49. Duran A, Carrero R, Parra B, Gonzalez A, Delgado L, Mosquera $\mathrm{J}$, et al. Association of lipid profile alterations with severe forms of dengue in humans. Arch Virol. 2015;160(7):1687-1692. 